\title{
A Demographic and Polysomnographic Investigation of Fatigue and Sleep Disorders in Patients with Multiple Sclerosis
}

\section{Multip I Skleroz Hastalarında Yorgunluk ve Uyku Bozukluklarının Demografik ve Polisomnografik Olarak Incelenmesi}

\author{
(D) Ali Özhan Sıvacı, (D) Aylin Bican Demir, (D) Ömer Faruk Turan, (D) Özlem Taşkapılığlu, (D) ibrahim Bora, (D) Gökhan Ocakoğlu* \\ Uludağ University Faculty of Medicine, Department of Neurology, Bursa, Turkey \\ *Uludağ University Faculty of Medicine, Department of Biostatistics, Bursa, Turkey
}

\begin{abstract}
Objective: To investigate fatigue and sleep disorders based on demographic, clinical and polysomnographic data and show their effects on the quality of life in multiple sclerosis (MS) patients.

Materials and Methods: Thirty MS patients were enrolled in the study depending on the results of the polysomnography (PSG), Fatigue Severity scale, Epworth Sleepiness scale (ESS), Pittsburgh Sleep Quality lindex, Beck Depression and Anxiety inventories. Patients, using $(n=16)$ and non-using $(n=14)$ interferon, were compared with each other in all parameters; ESS and PSG data were compared with a control group consisting of 19 healthy people. Short form-36 (SF-36) data were also compared with the society norms.

Results: Central fatigue was observed in $86.7 \%$ of the patients. PSG data revealed that stage N2 sleep duration of those who did not use interferon was significantly longer than those who used it $(p<0.001)$. According to the PSG, total sleep time, sleep efficiency, stage N3 and rapid eye movement time, mean respiratory disturbance index, sleep latency and the mean value of total leg movements were significantly higher in the patient group than in the control group $(p<0.001)$. All parameters of SF-36 were significantly lower in patient group $(p<0.001)$. The stage N3 sleep time length was found related with physical component summary of SF-36 $(\mathrm{p}<0.001)$.

Conclusion: MS patients have high level of fatigue and additionally there are weighty disturbances in objective and subjective sleep parameters. Our findings were revealed that all the components of quality of life decreased significantly in these patients. Furthermore, our study showed that deep sleep duration was related with physical activity and emphasized the importance of sleep evaluation in MS patients.

Keywords: Fatigue, sleep disorders, multiple sclerosis, polysomnography
\end{abstract}

Öz

Amaç: Multipl skleroz (MS) hastalarında demografik, klinik ve polisomnografik verilerle yorgunluk ve uyku bozukluklarını araştırmak ve yaşam kalitesi üzerine etkilerini göstermektir.

Gereç ve Yöntem: Çalışmaya polisomnografi (PSG), Yorgunluk Şiddeti ölçeği, Epworth Uykululuk ölçeği (EUÖ), Pittsburg Uyku Kalitesi indeksi, Beck Depresyon ve Anksiyete envanteri ile değerlendirilen 30 MS hastası alındı. Interferon kullanan $(n=16)$ ve kullanmayan $(n=14)$ hastalar, tüm parametrelerde birbirleriyle karşılaştıııldı; EUÖ ve PSG verileri 19 sağlıkı kişiden oluşan bir kontrol grubu ile karşılaştırıldı. Kısa form-36 (SF-36) verileri ise toplum normlarıyla karşılaştırıldı.

Bulgular: Hastaların \%86,7'sinde santral yorgunluk olduğu görüldü. PSG'de, interferon kullanmayanların evre N2 uyku süresi, kullananlara göre anlamlı olarak daha uzun kaydedildi $(p<0,001)$. PSG'ye göre, toplam uyku süresi, uyku etkinliği, evre N3 ve hızlı göz hareketi süresi, solunum bozukluğu indeksi ortalaması, uyku latansı ve toplam bacak hareketlerinin ortalama değeri, hasta grubunda kontrol grubuna göre anlamlı oranda yüksek bulundu $(p<0,001)$. SF-36'nın tüm parametreleri hastalarda anlamlı olarak daha düşüktü $(p<0,001)$. Evre N3 uyku süresi uzunluğu, SF-36'nın fiziksel bileşen özeti ile ilişkili bulundu $(p<0,001)$.

Sonuç: MS hastalarında yüksek düzeyde yorgunluk, ek olarak nesnel ve öznel uyku parametrelerinde önemli ölçüde bozukluklar bulunmaktadır. Çalışmamızda bu hastaların yaşam kalitesindeki tüm bileşenlerin önemli ölçüde azaldığı ortaya konmaktadır. Ayrıca çalışmamız derin uyku süresinin fiziksel aktivite ile ilişkili olduğunu göstermiş, MS hastalarında uyku değerlendirmesinin önemini vurgulamıştır.

Anahtar Kelimeler: Yorgunluk, uyku bozuklukları, multipl skleroz, polisomnografi 


\section{Introduction}

Multiple sclerosis (MS) is a chronic disease which affects the central nervous system, characterized by attacks and/ or progression caused by inflammation and demyelination in the optic nerve, brain, and spinal cord and usually seen in the young adult population $(1,2)$.

Chronic complaints which are frequently back claimed in clinical practice; it is as important as the attacks seen in the course of the disease and causing the disability. "Fatigue", seen in more than $80 \%$ of patients and defined as the 'most annoying' complaint by one in four of them, is one of the prolonged complaints that negatively affect the quality of life (3). Even though many clinical conditions, sleep disorders, and psychiatric illness have been associated with this complaint but the mechanism of fatigue in MS patients has not been clarified, yet $(4,5)$. Since there is no objective examination or laboratory test, different scales have been developed for fatigue diagnosis. "Fatigue Severity scale (FSS)" is one of the scales frequently used in MS patients and demonstrates fatigue (6).

It is of course expected that sleep disorders, which are very common in the general population, might exist as comorbid diseases in MS patients. In addition, symptoms such as pain, bladder dysfunction, side effects of medications, anxiety and depression are also known to affect sleep quality of the person with MS. However the studies done so far have shown that there is a close relationship between some sleep disorders and MS (7). For example, it was reported that the prevalence of Restless Legs syndrome (RLS) was four times higher in MS patients than in the normal population (8). In addition to subjective sleep scales, polysomnographic evaluation have been used more and more every day to correctly identify sleep disorders in MS patients (9).

It was proved by many studies that the quality of life in MS which is a progressive disease is influenced negatively by many factors. Fatigue and sleep disorders are independent factors that cause physical and mental disability leading to poor quality of life (10-12).

In the current study, it was aimed to show fatigue and sleep disorders seen in MS patients in the light of some demographic data and psychiatric conditions that may cause comorbidity. It was also aimed to reveal subjective and objective sleep data that might have an impact on the quality of life in MS patients who have complained about fatigue and sleep disturbances.

\section{Materials and Methods}

This study was conducted in accordance with the Declaration of Helsinki, and the approval of Uludağ University Medical Research Ethics Committee, dated 09.07.2015 and numbered 438.

\section{Participants}

Thirty MS patients, who had been admitted to the sleep clinic with complaints of fatigue and sleep disturbance and whose neurological evaluation and Expanded Disability Status scale (EDSS) scoring performed by a neurologist were enrolled in the study. In addition, these patients were evaluated with the Epworth Sleepiness scale (ESS), Pittsburg Sleep Quality index (PSQI) and were observed with polysomnography (PSG) overnight. Patients who did not have a definite diagnosis of MS, followed up with a clinical or radiologically isolated syndrome diagnosis, also who had a regular antidepressant use within the last three months were not included.

\section{Data Collection}

Demographic information of participants was recorded relation to age, gender, MS clinical subtype, EDSS score, immunomodulatory therapy (IMT) in practice. Beck depression (BECK-D) and Beck Anxiety scales (BECK-A) were administered to demonstrate the mood profile of these patients. Short form36 (SF-36) was used to assess the quality of life assessment. In terms of IMT, patients were divided into two groups; the ones $(n=16)$ using interferon (IFN) of which adverse effects on sleep have been reported many times, and the ones with other immunomodulatory drug treatments $(n=14)$. Fatigue levels, subjective and objective sleep data, psychometric evaluations and quality of life measures were analyzed comparatively between the patients using IFN and non-users. ESS and PSG values of the patients were compared with control group of 19 healthy individuals. Additionally, SF-36 scores are compared with normative data of Turkey which determined by 1279 healthy volunteers in 2006 (13).

\section{Statistical Analysis}

The normal distribution suitability of the variables was examined by the Shapiro-Wilk test. Variables were expressed as mean \pm standard deviation or median (minimum-maximum) values. Independent Double Sample t-test or Mann-Whitney $U$ test was used in the comparison between the groups according to the normality test result. Categorical variables were compared between groups using chi-square test. Statistical analyzes were performed using SPSS (IBM Corp. Released 2012. IBM SPSS Statistics for Windows, Version 21.0, Armonk, NY: IBM Corp.) A $p$ value of $<0.05$ was considered statistically significant.

\section{Results}

Of the 30 patients participated in the study, 20 (66.70\%) were female and 10 (33.30\%) were male; the mean age was found as 41 (20-62). The clinical subtypes of MS were $83.30 \%$ relapsing remitting type and $16.70 \%$ secondary progressive type. The EDSS scores were used as the main criteria for the disability of the patients. The median value of EDSS score was 2 (0-6). All participants were using IMT. IFN was used in 16 patients $(53.40 \%)$ and other drugs (Glatiramer acetate, Fingolimod, Natalizumab, Teriflunomide) were used in 14 patients (46.60\%) (Table 1).

According to BECK-D scale, $43.30 \%$ of the patients had various degrees of depression and $76.70 \%$ of the patients had anxiety disorder according to BECK-A scale. It was shown that there was no significant relationship between depression and IMT usage. Fatigue was observed in $86.70 \%$ of patients according to FSS. It was found that there were no significant correlations between the variables such as EDSS score, medication, psychometric evaluation which might have an effect on the fatigue scores (Table 1).

The data gathered with ESS revealed that 8 patients $(26.7 \%)$ had excessive daytime sleepiness. When compared with the control group this ratio was found to be similar (26.30\%) (Table 
1). Subjective bad sleep quality was determined in 26 patients (86.70\%) with PSQI total score and sleep quality of 4 patients (13.30\%) was evaluated normal (Table 1).

The number of patients who fulfilled the criteria for clinical RLS was $3(10 \%)$. It was also found that 9 patients (30\%) identified similar or imitator various complaints with RLS while 18 patients (60\%) had no complaints. Statistics of two subgroups as IFN users and non-users shown that there were no significant difference among fatigue, daytime sleepiness, subjective sleep quality parameters, psychometric measures, RLS findings and quality of life measures (Table 1).

According to PSG data; there were "fragmented sleep" findings (associated with insomnia) in 7 patients (23,3\%), Obstructive Sleep Apnea syndrome in 5 patients $(16,3 \%)$, "simple snoring" in 4 patients (13,3\%), periodic limb movement disorder (PLMD) in 3 patients (10\%) and "increased deep slow wave sleep" in 2 patients $(26,7 \%)$. Additionally 8 patients $(26,7 \%)$ were found to have normal objective sleep parameters (Table 2). It was also observed that the number of patients diagnosed as PLMD with PSG was $3(10 \%)$ and only one of them (3.33\%) met the clinical diagnostic criteria of RLS.

The polysomnographic evaluation of the patients was based on total recording time (TRT), total sleep time (TST), sleep latency (LAT), sleep efficiency (SE), duration of non-rapid eye movement (NREM) sleep stages (N1, N2, N3), REM sleep duration $(R)$, respiratory distress index (RDI), average oxygen saturation rate $\left(\mathrm{AvO}_{2}\right)$ and the number of total leg movement (TLM) parameters (Table 3 ). The determined PSG parameters were compared with the control group data. It was found out that TST, SE, N3, R and RDI median values were significantly higher in the control group $(p<0.001)$. On the other hand, in the patient group, LAT and TLM median values were found significantly higher than the control group $(p<0.001)$.

In addition, in the control group, the mean values of TRT and R were significantly higher than the patients' $(p<0.001)$ whereas the mean values of N1 and N2 were higher in the patient group. However, $\mathrm{AvO}_{2}$ values were not found significantly different between two groups (Table 4). When polysomnographic data were compared between subgroups which users and nonusers

\begin{tabular}{|c|c|c|c|c|c|c|}
\hline & $\begin{array}{l}\text { General } \\
(n=30)\end{array}$ & $\begin{array}{l}\text { IFN (+) } \\
(n=16)\end{array}$ & $\begin{array}{l}\text { IFN (-) } \\
(n=14)\end{array}$ & $\begin{array}{l}\text { IFN (+) and } \\
\text { IFN (-) p }\end{array}$ & $\begin{array}{l}\text { Control } \\
(n=19)\end{array}$ & $\begin{array}{l}\text { General } \\
\text { and control } p\end{array}$ \\
\hline Female/male & $20 / 10$ & $10 / 6$ & $10 / 4$ & 0.709 & $12 / 7$ & 0.801 \\
\hline Average age & $41.06 \pm 8.49$ & $42.12 \pm 8.49$ & $39.85 \pm 8.65$ & 0.476 & $30.15 \pm 5.49$ & 0.000 \\
\hline MS clinical type (RR/SP) & $25 / 5$ & $13 / 3$ & $12 / 2$ & 1.000 & - & - \\
\hline EDSS - median (min-max) & $2(0-6)$ & $2.5(0-6)$ & $2(0-5.5)$ & 0.759 & - & - \\
\hline FSS-fatigue (+/-) & $26 / 4$ & $14 / 2$ & $12 / 2$ & 1.000 & - & - \\
\hline ESS-sleepiness (+/-) & $8 / 22$ & $4 / 12$ & $4 / 10$ & 1.000 & $5 / 14$ & 0.978 \\
\hline PSQI-poor sleep (+/-) & $26 / 4$ & $13 / 3$ & $13 / 1$ & 0.602 & - & - \\
\hline $\operatorname{RLS}(+/-)$ & $3 / 27$ & $3 / 13$ & $0 / 14$ & - & - & - \\
\hline BECK-depression (+/-) & $13 / 17$ & $6 / 10$ & $7 / 7$ & 0.491 & - & - \\
\hline BECK-anxiety (+/-) & $23 / 7$ & $11 / 5$ & $12 / 2$ & 0.399 & - & - \\
\hline $\begin{array}{l}\text { SF-36-PCS-median } \\
\text { (min-max) }\end{array}$ & $\begin{array}{l}39.85 \\
(23.30-59.20)\end{array}$ & $\begin{array}{l}39.90 \\
(23.30-53.30)\end{array}$ & $\begin{array}{l}39.85 \\
(24.70-59.20)\end{array}$ & 1.000 & - & - \\
\hline $\begin{array}{l}\text { SF-36-MCS-median } \\
\text { (min-max) }\end{array}$ & $\begin{array}{l}40.15 \\
(23.20-60.70)\end{array}$ & $\begin{array}{l}40.15 \\
(26.00-58.90)\end{array}$ & $\begin{array}{l}39.60 \\
(23.20-60.70)\end{array}$ & 0.854 & - & - \\
\hline
\end{tabular}

\begin{tabular}{|l|l|l|}
\hline Table 2. Polisomnographic diagnoses & Patient (n) & Percentage \\
\hline Diagnose & 7 & $\% 23.3$ \\
\hline Fragmanted sleep & 5 & $\% 16.7$ \\
\hline OSA & 4 & $\% 13.3$ \\
\hline Simple snoring & 3 & $\% 10$ \\
\hline PLMD & 2 & $\% 6,7$ \\
\hline Increase of deep slow wave sleep & 1 & $\% 3.3$ \\
\hline RBD & 8 & $\% 26.7$ \\
\hline Normal & 30 & $\% 100$ \\
\hline Total & & \\
\hline OSA: Obstructive sleep apnea, PLMD: Periodic limb movement disorder, RBD: Rapid eye movement sleep behavior disorder & \\
\hline
\end{tabular}


of IFN, it was observed that the duration of N2 sleep was significantly longer in nonusers $(p<0.001)$ (Table 5$)$.

TST, LAT and SE data, which are common parameters in objective PSG measurements and in subjective PSQI scores which based on patients evaluations about their own sleep were compared each other. The results showed that there was no significant difference between subjective and objective evaluations of sleep in the light of these parameters. It was seen that there was no linear relationship between the PSQI scores of the patients and whether PSG diagnosis was normal or not.

\begin{tabular}{|l|l|l|l|l|}
\hline \multicolumn{5}{|l|}{ Table 3. Median values of polysomnographic parameters } \\
\hline $\begin{array}{l}\text { PSG } \\
\text { parameters }\end{array}$ & Patient (n) & Median & Minimum & Maximum \\
\hline TRT & 30 & 409.9 & 279 & 540 \\
\hline TST & 30 & 369 & 203.1 & 438 \\
\hline N1 & 30 & 23.2 & 5 & 56 \\
\hline N2 & 30 & 169.9 & 63.5 & 267.4 \\
\hline N3 & 30 & 88 & 19.5 & 196.2 \\
\hline R & 30 & 62.5 & 15.5 & 115.5 \\
\hline LAT & 30 & 15.2 & 1 & 360 \\
\hline SE & 30 & 86.8 & 45.2 & 97.2 \\
\hline RDI & 30 & 0.9 & 0 & 32 \\
\hline AvO ${ }_{2}$ sat. & 30 & 96.9 & 94 & 98.3 \\
\hline TLM & 30 & 9.4 & 0 & 393.9 \\
\hline TRT: & & &
\end{tabular}

TRT: Total recording time, TST: Total sleep time, N1: Stage N1, N2: Stage N2, N3: Stage N3, R: Rapid eye movement stage, LAT: Sleep latency, SE: Sleep efficiency, RDI: Respiratory distress Index, $\mathrm{AvO}_{2}$ : Average oxygen saturation rate, TLM: Total leg movement
When the patients were evaluated in terms of their quality of life, it was seen that all parameters of SF-36 were significantly below the social norms $(p<0.001)$ (Table 6$)$ The results of the study showed that there was no significant effect of IFN use on the quality of life. Also, no significant influence of the increase in EDSS scores on the physical and mental components of the quality of life was found.

When PSG data and the sub-parameters of SF- 36 were evaluated together, a significant correlation between the increase in N3 deep sleep duration in PSG and the high mean value of the physical component summary (PCS) of SF-36 was observed $(p<0.001)$. However, no statistically significant difference was found between the mental component summary (MCS) of SF-36 and patients' PSG results were evaluated as normal or pathological (Table 7).

\section{Discussion}

Fatigue, one of the most important problems that push patients out of everyday life, regardless of disability level of them, was found to be $86.7 \%$ high in the study, in accordance with many examples in the literature (14-16). Because there is no objective examination or diagnostic method, fatigue can be recognized and treated clinically only if the patient's statement can be understood correctly. While expressing this complaint, patients can describe many things such as fatigue, exhaustion, dementia, energy loss. Among these, the most frequently mentioned definition is daytime sleepiness (17). In the current study, while fatigue was discovered in $86.7 \%$ of the patients who frequently mentioned "fatigue" and "daytime sleepiness", excessive daytime sleepiness was found in only $26.7 \%$ according to the ESS scale. This result was found to

\begin{tabular}{|c|c|c|c|c|}
\hline & PSG parameters & $\begin{array}{l}\text { Patient } \\
(n=30)\end{array}$ & $\begin{array}{l}\text { Control } \\
(n=19)\end{array}$ & $p$ \\
\hline \multirow{7}{*}{ Median values } & $\begin{array}{l}\text { TST } \\
\text { (min-max) }\end{array}$ & $\begin{array}{l}369.00 \\
(203.10-438.70)\end{array}$ & $\begin{array}{l}401.00 \\
(385.00-441.00)\end{array}$ & 0.000 \\
\hline & $\begin{array}{l}\text { N3 } \\
\text { (min-max) }\end{array}$ & $\begin{array}{l}88.00 \\
(19.50-196.20)\end{array}$ & $\begin{array}{l}159.00 \\
(146.00-196.00)\end{array}$ & 0.000 \\
\hline & $\begin{array}{l}\text { LAT } \\
\text { (min-max) }\end{array}$ & $\begin{array}{l}15.25 \\
(1.00-360.00)\end{array}$ & $\begin{array}{l}6.00 \\
(2.00-14.00)\end{array}$ & 0.008 \\
\hline & $\begin{array}{l}\mathrm{SE} \\
(\min -\max )\end{array}$ & $\begin{array}{l}86.80 \\
(45.20-97.20)\end{array}$ & $\begin{array}{l}96.00 \\
(92.00-98.00)\end{array}$ & 0.000 \\
\hline & $\begin{array}{l}\text { RDI } \\
\text { (min-max) }\end{array}$ & $\begin{array}{l}0.95 \\
(0.00-32.00)\end{array}$ & $\begin{array}{l}2.00 \\
(1.00-6.00)\end{array}$ & 0.003 \\
\hline & $\begin{array}{l}\mathrm{AvO}_{2} \\
\text { (min-max) }\end{array}$ & $\begin{array}{l}96.90 \\
(93.60-98.30\end{array}$ & $\begin{array}{l}97.00 \\
(96.00-99.00)\end{array}$ & 0.334 \\
\hline & $\begin{array}{l}\text { TLM } \\
\text { (min-max) }\end{array}$ & $\begin{array}{l}9.45 \\
(0.00-393.90)\end{array}$ & $\begin{array}{l}1.00 \\
(0.00-4.00)\end{array}$ & 0.002 \\
\hline \multirow{4}{*}{ Mean values } & TRT & $416.52 \pm 52.06$ & $443.63 \pm 30.61$ & 0.046 \\
\hline & N1 & $25.55 \pm 14.11$ & $15.47 \pm 2.69$ & 0.001 \\
\hline & N2 & $172.60 \pm 54.27$ & $111.68 \pm 9.00$ & 0.000 \\
\hline & $R$ & $61.00 \pm 25.99$ & $97.10 \pm 8.47$ & 0.000 \\
\hline
\end{tabular}


be similar to the control group with no health problems. Moreover, when two data are evaluated together, it seems possible to claim that there was a clear distinction between these two complaints which were frequently expressed by patients in the same way. However, it should not be forgotten that central exhaustion may be a secondary symptom for a sleep disturbance.

There are many studies emphasizing the importance of polysomnographic evaluation in the management of fatigue (17-19). The most important contribution of PSG in this process is to be able to find out the possible accompanying or underlying sleep disorder. The result of the study revealed that there was no linear relationship between objective PSG findings of patients with fatigue and those without fatigue. The PSG findings were found to be normal in about one-third of patients who have severe fatigue shown by the FSS. On the other hand, when the PSG results of the patients without fatigue were examined, it was observed that none of them had a normal sleep diagnosis. It is obvious that poor sleep quality is not always the cause of fatigue. These different conditions

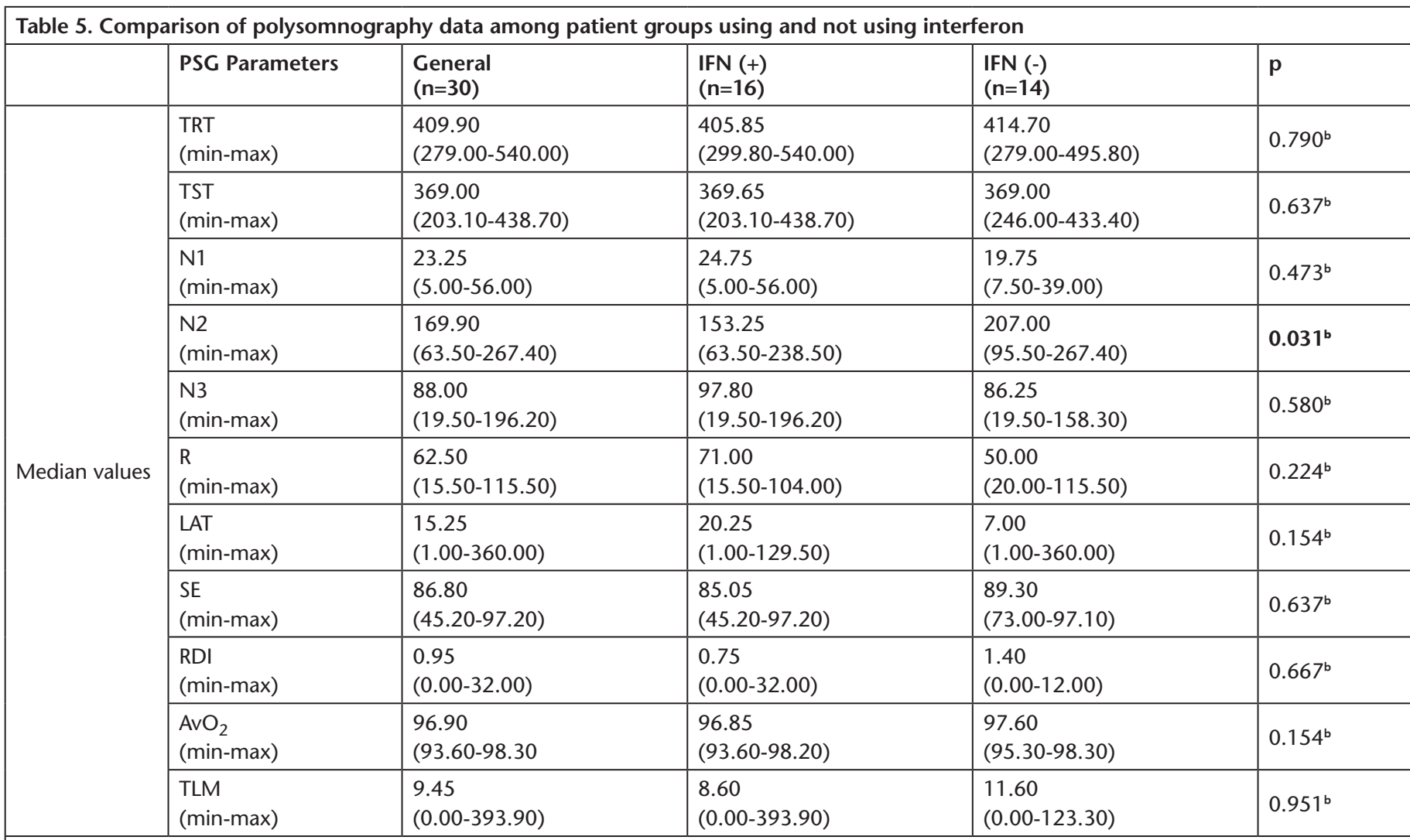

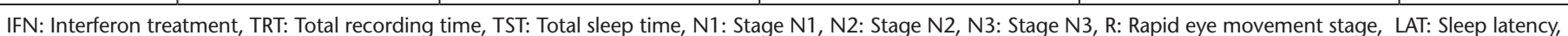
SE: Sleep efficiency, RDI: Respiratory distress Index, $\mathrm{AvO}_{2}$ : Average oxygen saturation rate, TLM: Total leg movement, min: Minimim, max: Maximum

\begin{tabular}{|c|c|c|c|c|}
\hline SF-36 & Patient (n) & Mean values & Standart deviation & $p$ \\
\hline PF & 30 & 57.6 & 27.4 & $<0.001$ \\
\hline $\mathrm{RP}$ & 30 & 47.5 & 40.1 & $<0.001$ \\
\hline $\mathrm{BP}$ & 30 & 63.8 & 23.8 & $<0.001$ \\
\hline $\mathrm{GH}$ & 30 & 39.8 & 17 & $<0.001$ \\
\hline VT & 30 & 30.6 & 18.2 & $<0.001$ \\
\hline SF & 30 & 59.9 & 26.9 & $<0.001$ \\
\hline RE & 30 & 60 & 37.5 & $<0.001$ \\
\hline $\mathrm{MH}$ & 30 & 56 & 18.3 & $<0.001$ \\
\hline PCS & 30 & 39.1 & 10.2 & $<0.001$ \\
\hline MCS & 30 & 40.5 & 9.2 & $<0.001$ \\
\hline
\end{tabular}




\begin{tabular}{|c|c|c|c|c|}
\hline \multicolumn{5}{|c|}{ 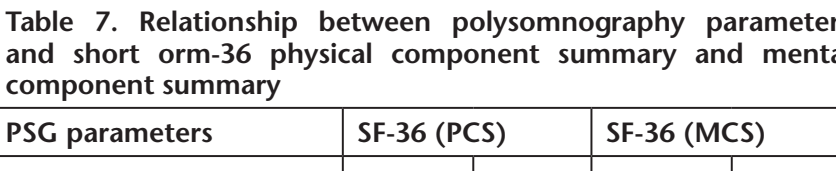 } \\
\hline & & $p$ & $r$ & $p$ \\
\hline TRT & 0.03 & 0.885 & -0.23 & 0.232 \\
\hline TST & 0.17 & 0.379 & -0.10 & 0.588 \\
\hline N1 & -0.12 & 0.530 & -0.04 & 0.844 \\
\hline N2 & -0.21 & 0.266 & 0.16 & 0.385 \\
\hline N3 & 0.42 & 0.021 & -0.19 & 0.326 \\
\hline $\mathrm{R}$ & 0.10 & 0.612 & -0.25 & 0.180 \\
\hline LAT & -0.32 & 0.087 & 0.31 & 0.098 \\
\hline SE & 0.24 & 0.199 & -0.06 & 0.765 \\
\hline RDI & -0.01 & 0.969 & -0.03 & 0.872 \\
\hline $\mathrm{AvO}_{2}$ & 0.05 & 0.778 & -0.09 & 0.629 \\
\hline TLM & 0.03 & 0.881 & 0.05 & 0.784 \\
\hline \multicolumn{5}{|c|}{$\begin{array}{l}\text { PSG: Polysomnography, PCS: Physical component summary, MCS: Mental } \\
\text { component summary TRT: Total recording time, TST: Total sleep time, N1: } \\
\text { Stage N1, N2: Stage N2, N3: Stage N3, R: Rapid eye movement stage, LAT: } \\
\text { Sleep latency, SE: Sleep efficiency, RDI: Respiratory distress Index, AvO }{ }_{2} \text { : Average } \\
\text { oxygen saturation rate, TLM: Total leg movement, r: Spearman correalation } \\
\text { coefficient, SF-36: Short form-36 }\end{array}$} \\
\hline
\end{tabular}

should be distinguished from each other, and PSG is one of the most important instruments for differential diagnosis.

Many studies have shown that fatigue increases with age and EDSS level (20). However, in our study, a significant effect of the demographic data including these two factors on fatigue could not be found.

Schreiber et al. (21) elaborated that the main factors contributing to fatigue in MS patients were personal characteristics, working with the body, to cope with the disease, anxiety, depression and these factors interacted with each other. Accordingly, especially high rates of depression and anxiety found in the patients suggest that fatigue is multifactorial.

Because of the neurodegenerative process, sleep quality in MS patients is far more important for a good learning, sustainable memory, new synapse formation and plasticity. There are many studies on sleep disorders in MS patients, approaching it from various angles $(9,17,22)$. Contrary to other studies, this subject was explored in a multidirectional and comprehensive way in our study.

It has been pointed out in many studies done so far $(23,24)$ that as the EDSS scores increase, fatigue and sleep disorder parameters may increase. However, in our study, no linear relationship was found. The patients with high EDSS scores who were followed up at the MS clinic, are less speaking out about sleep disturbances. In this respect, it is possible to claim that the patients may have to face more serious problems as multifunctional disabilities which seen in the high levels of EDSS. Which also not means that they have no complaints about fatigue and sleep disturbance.

In our study, it was observed that 12 patients had various complaints such as "uneasiness, discomfort in the legs". When these patients were evaluated with clinical RLS criteria, only 3 patients had definite RLS diagnosis. In MS patients, it is very important not to skip some clinical diagnoses such as RLS, but it is very significant to distinguish it from many imitator complaints such as muscle-joint aches, cramps, varicosities, spasticity, clonus, neuropathic pain and so on. In addition, it should be kept in mind that complaints frequently referred to "neuropathic pain" may also be a symptom for RLS in the MS patients. If the complaints of the patients are not explored by taking adequate time, any given treatment is likely to be unsuccessful.

It is obviously seen that subjective and objective sleep quality parameters in MS patients were distorted at different rates, whether sleep disorder was diagnosed in PSG or not. In a PSG-based study conducted by Chen et al. (19) with 21 MS patients and 11 controls, no significant difference in the duration of sleep in MS patients compared to controls was found. However, In our study, it was observed that N3 and R periods, which define deep sleep phases are very important for the cognitive skills and organization of the long time memory, were significantly shorter patients than the control group. In a PSG-based study conducted by Kaynak et al. (9) including 37 MS patients and 11 control group, N2, N3 and R sleep durations were found to be shorter in patients than in the control group. Moreover, in another study including $30 \mathrm{MS}$ patients and 30 control groups, it was claimed that $\mathrm{R}$ sleep duration was shortened in MS patients, which is consistent with the data of our study (17). All these results suggest that sleep disorders will worsen "learning and memory" problems commonly seen in MS patients.

It has been expressed many times in MS patients that IFN use contributes to sleep disorders (25). When we examined the objective PSG parameters among patients who did or did not use IFN in our study, N2 sleep duration was significantly longer in those who did not use IFN $(p<0.001)$. In the literature, studies that investigate the relationship between IFN use and objective PSG data are rare. In a study based on actigraphy data from 42 patients with MS in 2010 which performed by Mendozzi et al. (26), it has been noted that on the nights of IFN- $\beta$ injection, the sleep efficacy decreased by an average of $5 \%$ compared to other nights. In 2012, Braley and Chervin (27) conducted another study with $48 \mathrm{MS}$ patients, which was generally focused on the effect of using IMT on PSG data, and it was stated that only the apnea-hypopnea index decreased and the other parameters remained unchanged in patients which receiving IMT.

Regarding the use of IFN only, Raison et al. (28) conducted a study in 2010, which aimed to investigate the effects of IFNalpha use on the PSG parameters in 31 patients with hepatitis $C$ who did not previously complain about sleep disorder. The results of the study showed that the sleep efficacy and N3 sleep duration decreased in the group using IFN and REM latency and N2 sleep duration increased. However, in order to establish a healthy relationship between IFN use and PSG data, there is a need for further studies to be conducted with large populations of patients with standardized doses, frequency and duration of IFN use.

In our study, the sleep disorders frequently seen in MS patients who applied to the sleep clinic with complaints of fatigue and sleep disorders were defined respectively as insomnia related 
findings, sleep respiratory disorders and sleep movement disorders, and the data found to be consistent with many studies in the literature $(28,29)$. It is seen that the evaluation of MS patients with sleep disturbance by PSG and if necessary, to consult with a sleep disorder specialist will contribute to the quality of life of the patients.

The result of our study revealed that the quality of life scales of MS patients with various sleep disturbances were decreased significantly compared to the average of the society. Depending on the findings of our study, it is difficult to distinguish whether this is due to MS disease only or coexistence of MS and sleep disorder. However, new qualityof-life studies with MS patients with and without sleep disturbances may independently demonstrate the negative effect of sleep disturbances.

The results of a PSG and SF-36 based study with MS patients without any sleep disorder, conducted by Trojan et al. (22) in 2012, showed that sleep period changes, the number of awakening, N1 sleep duration, apnea-hypopnea index, and total arousal index values were inversely proportional to the SF-36 MCS (MCS). It was also found that TST, SE and $\mathrm{R}$ parameters were directly proportional to MCS, and no significant relationship between PCS and any PSG parameters was discovered. However, our study revealed that increase in N3 deep sleep duration evaluated by PSG was significantly related to the increase of PCS values $(p<0.001)$. This result needs to be underlined in terms of drawing attention to the importance of deep sleep in providing physical competence. There was no significant relationship between MCS and any parameters of PSG in our study. In addition, no significant difference was found between the mental component of the quality of life of the MS patients whose polysomnographic evaluative results were normal or pathological.

Our study was conducted with a limited number of MS patients with fatigue and sleep disturbance complaints. There is a need for extensive studies with a large number of randomly assigned MS patients. It is also important to make cognitive measurements of the patients to evaluate the results accordingly in studies where subjective scales are used. Our study did not assess the cognitive status of patients.

\section{Conclusion}

MS is an illness that affects the quality of life negatively at every stage of the disease, which also cause different kinds of disabilities. When this disease evaluated by the clinician, multidisciplinary approach is needed. The first and most important strategy for solving the problems faced by MS patients is to listen carefully to the complaints and to give enough time for the patient. The awareness of the treating physician in this regard will greatly contribute positively to the morbidity of the disease.

\section{Ethics}

Ethics Committee Approval: Approval from the Medical Research Ethics Committee of Uludağ University Faculty of Medicine, dated 09.07.2015 and numbered 438.

Informed Consent: This is retrospective study.

Peer-review: Internally peer-reviewed.

\section{Authorship Contributions}

Surgical and Medical Practices: A.Ö.S., A.B.D., Concept: Ö.F.T., Design: A.B.D., Data Collection or Processing: A.Ö.S., A.B.D., Analysis or Interpretation: G.O., Literature Search: Ö.T., I.B., Writing: A.Ö.S.

Conflict of interest: No conflict of interest was declared by the authors.

Financial Disclosure: Interms of study sponsorship (industry, government, or institutional) and all authors' financial relationships, we have none as this study was conducted trough our routine shift with our existing patients in the hospital we work, which is Uludag University Medical School. As a result, financial support was not necessary for this study to take place.

\section{References}

1. Sinnecker T, Mittelstaedt P, Dörr J, Pfueller CF, Harms L, Niendorf T, Paul F, Wuerfel J. Multiple sclerosis lesions and irreversible brain tissue damage: a comparative ultrahigh-field strength magnetic resonance imaging study. Arch Neurol 2012;69:739-45.

2. Goodin DS. The causal cascade to multiple sclerosis: a model for MS pathogenesis. PLoS One 2009;4:e4565.

3. Krupp LB, Alvarez LA, LaRocca NG, Scheinberg LC. Fatigue in multiple sclerosis. Arch Neurol 1988;45:435-7.

4. Roelcke U, Kappos L, Lechner-Scott J, Brunnschweiler H, Huber S, Ammann W, Plohmann A, Dellas S, Maguire RP, Missimer J, Radü EW, Steck A, Leenders KL. Reduced glucose metabolism in the frontal cortex and basal ganglia of multiple sclerosis patients with fatigue: a 18F-fluorodeoxyglucose positron emission tomography study. Neurology 1997;48:156-7.

5. Flachenecker P, Bihler I, Weber F, Gottschalk M, Toyka KV, Rieckmann P. Cytokine mRNA expression in patients with multiple sclerosis and fatigue. Mult Scler. 2004;10:165-9.

6. Krupp L, Larocca N, Muir-Nash J, Steinberg A. The Fatigue Severity Scale. Application to patients with multiple sclerosis and systemic lupus erythematosus. Arch Neurol 1989;46:1121-3.

7. Merlino G, Fratticci L, Lenchig C, Valente M, Cargnelutti D, Picello M, Serafini A, Dolso P, Gigli GL. Prevalence of 'poor sleep' among patients with multiple sclerosis: an independent predictor of mental and physical status. Sleep Med 2009;10:26-34.

8. Italian REMS Study Group, Manconi M, Ferini-Strambi L, Filippi M, Bonanni E, ludice A, Murri L, Gigli GL, Fratticci L, Merlino G, Terzano G, Granella F, Parrino L, Silvestri R, Aricò I, Dattola V, Russo G, Luongo C, Cicolin A, Tribolo A, Cavalla P, Savarese M, Trojano M, Ottaviano S, Cirignotta F, Simioni V, Salvi F, Mondino F, Perla F, Chinaglia G, Zuliani C, Cesnik E, Granieri E, Placidi F, Palmieri MG, Manni R, Terzaghi M, Bergamaschi R, Rocchi R, Ulivelli M, Bartalini S, Ferri R, Lo Fermo $S$, Ubiali E, Viscardi M, Rottoli M, Nobili L, Protti A, Ferrillo F, Allena M, Mancardi G, Guarnieri B, Londrillo F. Multicenter case-control study on restless legs syndrome in multiple sclerosis: the REMS study. Sleep 2008;31:944-52.

9. Kaynak H, Altintas A, Kaynak D, Uyanik O, Saip S, Ağaoğlu J, Onder $G$, Siva A. Fatigue and sleep disturbance in multiple sclerosis. Eur I Neurol 2006;13:1333-9.

10. The FAMS study group. Predictors of quality of life among patients with multiple sclerosis: an Italian cross-sectional study. J Neurol Sci 2007;252:121-9.

11. Benito-Leon J, Morales JM, Rivera-Navarro J. Health-related quality of life and its relationship to cognitive and emotional functioning in multiple sclerosis patients. Eur J Neurol 2002;9:497-502.

12. Miller DM, Rudick RA, Baier M, Cutter G, Doughtery DS, WeinstockGuttman B, Mass MK, Fisher E, Simonian N. Factors that predict 
health-related quality of life in patients with relapsing-remitting multiple sclerosis. Mult Scler 2003;9:1-5.

13. Demiral Y, Ergor G, Unal B, Semin S, Akvardar Y, Kıvırcık B, Alptekin K. Normative data and discriminative properties of short form 36 (SF36) in Turkish urban population. BMC Public Health 2006;6:247.

14. Krupp L. Fatigue is intrinsic to multiple sclerosis (MS) and is the most commonly reported symptom of the disease. Mult Scler 2006; 12:367-8.

15. Lerdal A, Celius E, Krupp L, Dahl AA. A prospective study of patterns of fatigue in multiple sclerosis. Eur J Neurol 2007;14:1338-43.

16. Veauthier C, Radbruch H, Gaede G, Pfueller CF, Dörr J, BellmannStrobl J, Wernecke KD, Zipp F, Paul F, Sieb JP. Fatigue in multiple sclerosis is closely related to sleep disorders: a polysomnographic cross-sectional study. Mult Scler 2011;17:613-22.

17. Braley T, Chervin R, Segal B. Fatigue, tiredness, lack of energy, and sleepiness in multiple sclerosis patients referred for clinical polysomnography. Mult Scler Int 2012;2012:673936.

18. Veauthier C. Sleep disorders in multiple sclerosis. Review. Curr Neurol Neurosci Rep 2015;15:21.

19. Chen JH, Liu XQ, Sun HY, Huang Y. Sleep disorders in multiple sclerosis in China: clinical, polysomnography study, and review of the literature. J Clin Neurophysiol 2014;31:375-81.

20. Weinges-Evers N, Brandt AU, Bock M, Pfueller CF, Dörr J, BellmannStrobl I, Scherer P, Urbanek C, Boers C, Ohlraun S, Zipp F, Paul F. Correlation of self-assessed fatigue and alertness in multiple sclerosis. Mult Scler 2010;16:1134-40.

21. Schreiber K, Oturai AB, Ryder LP, Madsen HO, Jorgensen OS, Svejgaard A, Sorensen PS. Disease severity in Danish multiple sclerosis patients evaluated by MRI and three genetic markers (HLA-DRB1* 1501, CCR5 deletion mutation, apolipoprotein E). Mult Scler 2002;8:295-8.

22. Trojan D, Kaminska M, Bar-Or A, Benedetti A, Lapierre Y, Da Costa D, Robinson A, Cardoso M, Schwartzman K, Kimoff RJ. Polysomnographic measures of disturbed sleep are associated with reduced quality of life in multiple sclerosis. J Neurol Sci 2012;316:158-63.

23. Neau JP, Paquereau J, Auche V, Mathis S, Godeneche G, Ciron J, Moinot N, Bouche G. Sleep disorders and multiple sclerosis: a clinical and polysomnography study. Eur Neurol 2012;68:8-15.

24. Bamer AM, Johnson KL, Amtmann D, Kraft GH. Prevalence of sleep problems in individuals with multiple sclerosis. Mult Scler 2008; 14:1127-30.

25. Jankovic S. Injectable interferon beta- $1 \mathrm{~b}$ for the treatment of relapsing forms of multiple sclerosis. J Inflamm Res 2010;3:25-31.

26. Mendozzi L, Tronci F, Garegnani M, Pugnetti L. Sleep disturbance and fatigue in mild relapsing remitting multiple sclerosis patients on chronic immunomodulant therapy: an actigraphic study. Mult Scler 2010;16:238-47.

27. Braley TJ, Chervin RD. A practical approach to the diagnosis and management of sleep disorders in patients with multiple sclerosis. Ther Adv Neurol Disord 2015;8:294-310.

28. Raison CL, Rye DB, Woolwine BJ, Vogt G], Bautista BM, Spivey JR, Miller $\mathrm{AH}$. Chronic interferon-alpha administration disrupts sleep continuity and depth in patients with hepatitis C: association with fatigue, motor slowing, and increased evening cortisol. Biol Psychiatry 2010;68:942-9.

29. Stanton B, Barnes F, Silber E. Sleep and fatigue in multiple sclerosis. Mult Scler 2006;12:481-6. 